\title{
Persepsi kepercayaan dan orientasi mahasiswa dalam pemanfaatan belanja daring
}

\author{
Anugrah Mahirah Al Kharisma, Ananda Nur Azahra, Davin Wahyu Widodo, Mifta \\ Huljannah, Kiki Amelia Sari, Rita Arsyantie, Ananda Dwitha Yuniar* \\ Universitas Negeri Malang, Jl. Semarang No. 5 Malang, Jawa Timur, Indonesia \\ *Penulis korespondensi, Surel: ananda.dwitha.fis@um.ac.id
}

Paper received: 03-02-2021; revised: 15-02-2021; accepted: 28-02-2021

\begin{abstract}
In the increasingly rapid development of science and technology, it is inseparable from several problems, especially the misuse of technology in everyday life, such as cyber crime or crimes committed in cyberspace. This article aims to determine the trust of 2019 FIS UM students in the practice of buying and selling online. This article uses the concept of dramaturgy which explains how humans live their lives by acting and considers that the universe is actually a stage as a place to play for the people. In this concept, it focuses on how the behavior patterns that occur in an individual are tied to how existing actions are in society. This article uses a descriptive qualitative method with the research subjects being students of the State University of Malang class 2019. The results of this article indicate that students of the State University of Malang have done online shopping and some of them have positive and negative perceptions about online shopping activities.
\end{abstract}

Keywords: online shopping; fraud; cyber crime.

\begin{abstract}
Abstrak
Dalam perkembangan ilmu pengetahuan dan teknologi yang semakin pesat, tidak terlepas dari beberapa permasalahan terutama penyalahgunaan teknologi dalam kehidupan sehari-hari, seperti cyber crime atau kejahatan yang dilakukan di dunia maya. Artikel ini bertujuan untuk mengetahui kepercayaan mahasiswa FIS UM angkatan 2019 pada praktek jual beli secara online. Artikel ini menggunakan Konsep dramaturgi yang menjelaskan tentang bagaimana manusia menjalankan kehidupan mereka dengan bersandiwara dan menganggap bahwa sebenarnya jagat raya ini adalah sebuah panggung sebagai tempat untuk bersandiwara bagi para masyarakat. pada konsep ini, menitikberatkan tentang bagaimana pola perilaku yang terjadi pada suatu individu terikat dari bagaimana tindakan yang ada pada masyarakat. Artikel ini menggunakan metode kualitatif deskriptif dengan subjek penelitiannyaadalah mahasiswa Universitas Negeri Malang angkatan 2019. Hasil dari artikel ini menunjukkan bahwa mahasiswa Universitas Negeri Malang pernah melakukan belanja secara online dan beberapa diantaranya memiliki persepsi positif dan negatif mengenai kegiatan belanja secara online.
\end{abstract}

Kata kunci: belanja online; penipuan; cyber crime.

\section{Pendahuluan}

Pada saat ini, perkembangan ilmu pengetahuan dan teknologi berkembang semakin pesat. Maraknya perkembangan IPTEK ini nyatanya dihadapkan dengan sebuah permasalahan yang pelik di masyarakat, dibuktikan dengan penyalahgunaan teknologi dalam kehidupan sehari-hari yang masih saja ada di kalangan masyarakat. Salah satu contohnya adalah cyber crime atau sebuah istilah bagi kejahatan yang dilakukan di dunia maya. Dr.Barda Nawawi Arief, S.H. Menyatakan bahwa cybercrime merupakan kejahatan yang terjadi melalui teknologi dan 
akses informasi dan terdapat dalam dunia virtual atau dunia maya yang bertujuan untuk merugikan pihak lain. (Suhariyanto, 2012:11)

Selanjutnya menurut (Dikdik M. Arief Mansur dan Elisataris Gultom (2005: 10) dalam Jayanto, 2013) cyber crime merupakan sebuah bentuk dan tindakan yang bersifat pidana yang kaitannya sistem informasi. Sehingga, bisa dikatakan cyber crime merupakan sebuah bentuk kejahatan yang terjadi di dunia maya. Salah satu bentuk cyber crime adalah penipuan dalam pembelian yang dilakukan secara daring atau online, penipuan ini sering terjadi dikarenakan dengan tampilan harga yang bisa dikatakan murah dan barang yang sedang populer. Penipuan ini tak memandang gender, laki - laki dan perempuan juga bisa terkena penipuan dalam pembelian di online shop. Misalnya saja yang terjadi pada mahasiswa baru Fakultas Ilmu Sosial Universitas Negeri Malang 2019 di salah satu online shop, yang berinisial D, dia mengaku pernah mengalami penipuan online shop di salah satu media sosial yaitu instagram. D menyatakan bahwa, dia tertipu oleh toko online saat ingin membeli sepatu. Kerugian yang di alami berkisar Rp.500.000.

Tindakan penipuan ini termasuk tindakan kriminal dan juga dapat membuat pelaku yang melakukannya terjerat hukum yang ada. Dalam (RUU KUHP pasal 378) yang berbunyi "barang siapa dengan maksud menguntungkan diri sendiri atau orang lain dengan melawan hukum, dengan memakai nama palsu atau martabat palsu, dengan tipu muslihat apapun dengan rangkaian kebohongan menggerakkan orang lain untuk menyerahkan sesuatu benda kepadanya, atau supaya member hutang maupun menghapuskan piutang, diancam karena penipuan dengan pidana penjara paling lama selama 4 tahun". Kemudian bisa juga dijerat dengan UU No. 11 tahun 2008 tentang informasi dan transaksi elektronik (UU ITE).

\section{Metode}

Dalam penelitian ini, penulis menggunakan jenis penelitian kualitatif deskriptif. Bodgan dan Taylor penelitian kualitatif adalah prosedur penelitian yang menggunakan data deskriptif yang berupa kata-kata tertulis atau lisan dari perilaku yang diamati.Menurut mereka penkdekatan ini diarahkan pada luar dan individu tersebut secara holistic (utuh) (Moleong, 2007: 4). Fokus dalam penelitian ini adalah menggambarkan kerpercayaan mahasiswa baru Fakultas Ilmu Sosial Universitas Negeri Malang dalam menggunakan online shop. Lokasi yang di pilih yaitu di Fakultas Ilmu Sosial Universitas Negeri Malang. Subjek penelitian ini adalah mahasiswa baru Fakultas Ilmu Sosial Universitas Negeri Malang 2019. Dalam pengumpulan data, penulis menggunakan teknik wawancara. Informan yang digunakan sebanyak 10 orang yang pernah mengalami penipuan online shop. Metode narasumber didapakan melalui purposive sampling. Wawancara ini berfokus pada bagaimana kepercayaan mahasiswa baru angkatan 2019 Fakultas Ilmu Sosial Universitas Negeri Malang pada praktik online shop.

\section{Hasil dan Pembahasan}

Dari hasil penelitian yang di lakukan melalui 10 narasumber ini dapat diketahui bahwa sebanyak 10 mahasiswa baru Fakultas Ilmu Sosial Universitas Negeri Malang pernah melakukan belanja secara online. Dalam melakukan belanja secara online tersebut dapat dilakukan melalui berbagai sumber, seperti media sosial dan startup. Dengan berkembangnya teknologi yang pesat seperti sekarang, belanja online telah menjadi alternatif bagi para masyarakat, terutama para Mahasiswa, karena mereka mendapatkan berbagai manfaat, diantaranya kemudahan dan efisiensi waktu. Dalam melakukan belanja secara online, Mahasiswa harus lebih selektif dalam memilih toko online yang akan dikunjungi. Mahasiswa 
memiliki kriteria tersendiri dalam memilih toko online. Mereka biasanya memilih toko online yang memiliki penilaian dan ulasan yang bagus, berdasarkan pengalaman dari orang lain dan rekomendasi dari para selebriti.Saat melakukan pembelanjaan secara online, 4 dari 10 mahasiswa merasakan senang dan tidak sabar dalam menunggu barang yang dipesan. Sedangkan 3 mahasiswa merasakan takut dan tidak tenang, jika barang yang mereka pesan tidak sampai ke tangan mereka. Dan sisanya mereka merasa aman, karena mereka belanja di toko online yang terpercaya.

Disamping memiliki manfaat berupa kemudahan dan efesiensi waktu, belanja secara online juga memiliki dampak negatif, salah satunya adalah penipuan. Dari 10 mahasiswa, mereka menyatakan bahwa mereka pernah mengalami penipuan saat melakukan belanja secara online. Bentuk bentuk penipuan yang mereka alami seperti, produk yang mereka pesan tidak sesuai dengan penjelasan, penjual mengajak transaksi diluar aplikasi, penjual memutuskan kontak setelah transaksi, padahal barang belum sampai ketangan pembeli. Banyak faktor yang menyebabkan penjual terjerumus kedalam penipuan belanja online, diantaranya mereka tergiur dengan harga yang rendah di pasaran, dan kurang selektifnya dalam memilih toko online. Setelah mengalami penipuan dalam pembelanjaan online, mahasiswa tetap melakukan pembelanjaan secara online tetapi mereka menjadikan pengalaman sebelumnya sebagai acuan saat melakukan pembelanjaan secara online.

Berdasarkan hasil wawancara yang kami teliti terdapat 10 informan mahasiswa baru FIS UM 2019 yang pernah melakukan belanja online shop. Dari setiap informan memiliki jawaban yang berbeda mengenai bagaimana cara mencari dan memilah toko online yang akan di kunjungi. Ada factor utama yang menjadi sarana pemilihan toko online shop yaitu adanya influencer. Adanya influencer yang sangat populer di kalangan milenial zaman sekarang sangat mempengaruhi para pengguna media sosial, termasuk dalam hal mencoba dan membeli sebuah produk. Seorang influencer mampu menarik perhatian pengguna media social melalui postingan berupa instagram story, video maupun foto. Dengan adanya pengaruh influencer terhadap ulasan-ulasan terbaik yang di sampaikan mengenai suatu produk yang di tawarkan, para pengguna media sosial tentunya akan memiliki ketertarikan dan keinginan untuk membeli suatu produk dalam online shop yang di tawarkan. Terlebih lagi seorang influencer adalah orang yang memiliki tingkat kepercayaan yang tinggi sehingga barang yang di tawarkan pun juga akan terpercaya. Kegiatan pemasaran oleh influencer ini memiliki kualitas dan nilai yang baik melalui testimoninya. Hal ini berdampak pada kepercayaan konsumen terhadap pemilihan suatu perbelanjaan online.

Kemudian hasil wawancara menunjukkan bahwa informan memikirkan dua hal dalam pembelanjaan via online ini yaitu pemikiran negatif dan pemikiran positif. Pemikiran negatif yang muncul yaitu konsumen mengalami rasa ketakutan dan keraguan terhadap pembelian melalui online. Ketika kita telah melakukan pembelian produk secara online seringkali kita dihadapkan dengan rasa ketakutan dan keraguan dalam kegiatan pembelanjaan online. Apakah produk yang kita beli akan sampai ketangan konsumen ataukah akan berujung pada sebuah penipuan. Karena adanya proses jual-beli online ini pada dasarnya tidak ada pertemuan langsung antara penjual dan pembeli, tetapi ada beberapa online shop yang masih memakai sistem COD atau Cash on Delivery. Selain konsumen merasa takut dan ragu dalam pembelanjaan online ini, konsumen juga memikirkan hal positif dalam pembelanjaan via online yaitu adanya rasa excited terhadap produk yang di beli. Hal ini dibuktikan melalui wawancara dari beberapa informan. 
Selanjutnya hasil wawancara memperlihatkan bahwa informan merasa tertipu pada saat berbelanja online. Hal ini berkaitan dengan konsep dramaturgi, dimana seorang penjahat dalam konteks penelitian ini sebagai penipu dalam proses jual beli online, dan mahasiswa sebagai korban di dalam proses jual beli online. Pelaku penipuan online shop ini mulai melakukan aksinya melalui komunikasi. Komunikasi tersebut di lakukan melalui media sosial instagram. Ada beberapa model modus penipuan yang dilakukan oleh para penjual online shop, seperti dengan menunda-nunda waktu pengiriman. Awalnya penjual online shop ini memperlakukan konsumen dengan sangat baik, namun setelah konsumen tertarik untuk membeli produk lalu mentransfer sejumlah uang, penjual online shop menghilang perlahanlahan. Mulai dari beralasan penundaan pengiriman sampai ke penipu memblokir berbagai media sosial konsumen. Lalu, penipu juga melakukan modus penipuan lain seperti menunjukkan testimoni palsu agar konsumen tertarik dan percaya bahwa produk yang diperjual- belikan ready.

Dari informasi yang di dapat dari hasil wawancara, respon mahasiswa baru FIS UM 2019 menyatakan bahwa mereka tetap akan melakukan pembelanjaan produk-produk via online. Dari penipuan yang pernah mereka alami, mereka lebih akan berhati-hati dan lebih selektif lagi dalam berbelanja online agar tidak terulang kembali. Bahkan beberapa informan sudah mengerti tips dan trik dalam pemilihan pembelanjaan online seperti dalam pemilihan toko online "Shopee" dilihat dari banyaknya orang yang membeli produk tersebut dan banyaknya pemberian bintang pada suatu produk tersebut. Kemudian dari instagram penilaian di lihat dari jumlah followers, testimoni, harga produk serta deskripsi produk tersebut.

\section{Simpulan}

Belanja bisa disebut dengan kebutuhan yang haruslah dilakukan setiap manusia. Belanja bisa dilakukan di berbagai tempat, waktu dan kapan sekiranya itu harus dilakukan. Begitupun rasa kepuasaan manusia terhadap sesuatu haruslah benar-benar bisa membuat hasrat ketika membeli barang itu merasa puas.Jika tidak "konsumen" sebutan untuk pembeli dari orang menjual, itu pun merasa dirugikan. Seiring bertambahnya ilmu pengetahuan maupun teknologi semakin gencar pula orang berlomba-lomba membelanjakan daganganya. Mulai dari kebutuhan pokok sampai ke primer. Mereka membuat barang dagangan dengan khas dari penjual tersebut. Jika dirasa konsumen sudah puas dan merasa banyak yang membeli disitulah titik kepuasan penjual sebagai "pengproduksi". Karena banyak halter sebutlah berkembang ilmu pengetahuan tentang "distribusi" atau yang menyalurkan barang dari penjual ketangan pembeli langsung. Semua sudah dibuktikan jika belanja melalui teknologi yang istilanya sekarang online shop .Banyak oknum yang mengabil kesempatan tersebut untuk melakukan hal kecurangan didalamnya. Oknum nakal yang melakukan tersebut dapat membaca situasi yang sedang marak terjadi sekarang. Dengan kekuatan media social oknum nakal berhasil membujuk korbanya untuk membeli dan mengikuti perintahnya. Tidak dapat dipungkiri semua berawal dari kebutuhan, hingga konsumen percayaakan bujukan penjual yang ada di online tersebut. Penipuan-penipuan di online shop banyak jenisnya, dari penipuan barang, jasa bahkan hipnotis yang membuat konsumen tertarik untuk membeli. Pada masa remaja, mereka juga lebih rentan terkena bujuk rayu dari penjual. Untuk itu seharusnya konsumen harus lebih bijak ketika disuruh membeli barang di online shop, karena kejahatan didalamnya yang sangat banyak. Konsumen diharapkan mampu lebih bijak mengambil tindakan akan hal yang serasa membuat mereka rugi. Oleh karena itu pengetahuan akan kejahatan media social harus sangat didalami agar tidak terjadi hal yang merugikan siapapun. Dari pemerintah sendiri sudah memberikan sangsi kepada penjahat online, namun bukan saja dari pemerintah yang lebih 
ditekankan. Untuk menjaga diri sendiri, kita harus dengan dari kita sendiri. Karena pemerintah saja tidak cukup dan bahkan penjahat online masih marak berkembang.

\section{Daftar Rujukan}

Alam Syah.T (2013).TIK, D. T. I. D. K. Makalah Dampak Teknologi Informasi dan Komunikasi (TIK) terhadap Aktivitas Pendidikan Sekolah Dasar.

https://kbbi.kemdikbud.go.id/ diakses pada 27, November 2019

Jayanto, T. E., Tasir, S., \& Pratimaratri, U. (2013). Tindak pidana sara yang dilakukan melalui media internet (Studi Terhadap Perkara Pidana No: 45/PID/B/2012. PN. MR.). Abstract of Undergraduate Research, Faculty of Law, Bung Hatta University, 3(1).

Kitab Undang Undang Hukum Pidana Pasal 378

Lusiana, A. (2018). Maraknya penipuan online (bisnis online shop) ditinjau dari sudut pandang actus humanus manusia "Tahu, Mau, \& Bebas".

Mansur, D. M. A. (2005). Cyber Law: Aspek Hukum Teknologi Informasi. Tiga Serangkai.

Moleong, Lexy J. (2007). Metodologi Penelitian Kualitatif. Bandung: PT Remaja Rosdakarya

Nurrahmanto, P. A., \& Rahardja, E. (2015). Pengaruh kemudahan penggunaan, kenikmatan berbelanja, pengalaman berbelanja dan kepercayaan konsumen terhadap minat beli konsumen di situs jual beli online bukalapak. com (Doctoral dissertation, Fakultas Ekonomika dan Bisnis).

Nurwita, I., Ariprahara, G., \& Wirasari, I. (2015). Perancangan Kampanye Waspada Penipuan Saat Belanja Online. EProceedings of Art \& Design, 2(2).

Rusmana, A. (2015). Penipuan dalam interaksi melalui media sosial (kasus peristiwa penipuan melalui media sosial dalam masyarakat berjejaring). Jurnal Kajian Informasi \& Perpustakaan, 3(2), 187-194.

Sari, C. A. (2015). Perilaku berbelanja online di kalangan mahasiswi antropologi Universitas Airlangga. J UNAIR IV (2), 205-216.

Sumenge, M. (2013). Penipuan Menggunakan Media Internet Berupa Jual-Beli Online. Lex Crimen, 2(4).

Suhariyanto, B. (2012). Tindak Pidana Teknologi Informasi (Cybercrime). Raja Graffindo Persada, Jakarta.

Suneki, S., \& Haryono, H. (2012). Paradigma Teori Dramaturgi terhadap Kehidupan Sosial. CIVIS, 2(2/Juli).1 Undang undang informasi dan transaksi online

Yulianto, Y., Alfiah, F., Harahap, E. P., Pahad, B. A., Andriyanto, A., Azhari, I. A., \& Saputra, R. S. (2015). Analisa Peranan Teknologi Internet Sebagai Media Transaksi E-Commerce Dalam Meningkatkan Perkembangan Ekonomi. Semnasteknomedia Online, 3(1), 4-1. 